\title{
MOLECULAR CHARACTERIZATION OF SALMONELLA SPECIES ISOLATED FROM CHICKEN TABLE EGG CONTENT
}

\author{
SABER, A.S. ${ }^{1}$ and ABEER H.A. ${ }^{2}$ \\ ${ }^{1}$ Animal Health Research Institute, Damanhour Branch, Egypt \\ ${ }^{2}$ Animal Health Research Institute, Alexandria Branch, Egypt
}

Received: 16 May 2019; Accepted: 13 June 2019

\begin{abstract}
Salmonellosis is a foodborne illness caused by consumption of contaminated food. Infected raw or undercooked eggs are one of the major causes of salmonellosis, which lead to many public health problems. The aim of this study is isolation and identification of Salmonella spp. from the egg content samples, in addition, detection of some virulence gene ( $a v r \mathrm{~A}$, invA and stn). Four hundred edible farm and balady eggs (200 of each) were randomly collected from different supermarkets and farms in El-Behera Governorate, Egypt. The obtained results revealed that the incidence of Salmonella species were 1 and 3\% in examined farm and balady eggs, respectively and also $1 \%$ in balady eggs while couldn't be detected in farm eggs by direct molecular target genes detection. Serotyping of Salmonella isolates revealed that two different Salmonella serotypes were identified as; $S$. enteritidis (1strain), $S$. typhimurium (1 strain) from farm eggs and $S$. enteritidis (5 strains) and $S$. typhimurium (1 strain) from balady eggs. Six isolates of Salmonella serovars were molecularly identified, all had avrA gene at $422 \mathrm{bp}$, invA gene at $284 \mathrm{bp}$ and stn gene at $617 \mathrm{bp}$. In addition direct detection of virulence gene from egg content of ten egg samples for Salmonella revealed that 2 samples from balady eggs contain all target virulence genes (avrA, invA and stn) with amplified products 422, 284 and $617 \mathrm{bp}$, respectively. Presence of invA, avrA and stn gene in all isolates indicated that they are capable of producing gastroenteric illness to humans.
\end{abstract}

Key Words: S. enteritidis, $S$. typhimurium, edible eggs, virulence genes, PCR.

\section{INTRODUCTION}

Egg is an ideal source of nutrients for proliferation of both spoilage and pathogenic contaminating microorganisms. Fresh egg has three structures, which are an outer waxy shell membrane, the shell and the inner shell membrane and each is effective to some degree of retarding the entry of microorganisms (Jay et al., 2005).

Consumers prefer the egg in which the albumen is firm, the yolk has a dense color, the egg is of an appropriate size with intact shell, and is free from pathogens (Samiullah and Chousalkar, 2014).

Salmonella is a genus of rod-shaped (bacillus) Gram-negative bacteria of family Enterobacteriaceae. The two species of Salmonella are Salmonella enterica and Salmonella bongori $S$. enterica is the type species and is further divided into six subspecies that include over 2,600 serotypes (Gal-Mor et al., 2014).

Corresponding author: Dr. SABER, A.S.

E-mail address: sabersaad284@yahoo.com

Present address: Animal Health Research Institute, Damanhour Branch, Egypt
Eggs are contaminated with Salmonella by two routes; vertical transmission by transport Salmonella from infected reproductive tissues to egg prior to shell formation and horizontal transmission by contamination of egg shell with animal feces and through environmental vectors such as farmers, pets and rodents. Improperly storage and shell damage may facilitate contamination with Salmonella (Poppe et al., 1998).

Salmonellae considered as the most common bacteria-contaminating egg shell (Ricke et al., 2001). Salmonella enteritidis and Salmonella typhimurium are the most frequent Salmonella serotypes found inside the eggs that caused food poisoning. In addition, the organism causes human salmonellosis, which may range from gastroenteritis to typhoid (Tan et al., 2012).

Salmonella enteritidis is considered an emerging predominant serotype isolated from poultry eggs (Huehn et al., 2010). Salmonella enterica serovar enteritidis have the capability to infect developing eggs within the oviduct, and therefore contaminated eggs act as an ecological amplifier (Gast et al., 2011). 
Complex pathogenesis is characteristic of Salmonella infection. The virulence of Salmonella is encoded by multiple genes, which are clustered on Salmonella pathogenicity islands (SPIs). SPIs have the potential to contribute to the overall pathogenesis of the bacterium (Hensel, 2004). Genomic variability among bacterial strains arises primarily because of horizontal gene transfer (Suez et al., 2013). This inherent variability is likely the source of the various pathogenicities among non-typhoidal Salmonella strains. Consequently, characterization of the virulence gene repertoire by PCR has been used to profile the virulence of Salmonella (Shah et al., 2011).

Salmonella-specific PCR test in conjunction with traditional isolation methods could be effective in providing a more accurate profile of the prevalence of Salmonella in poultry products such as eggs (Ahmed et al., 2014). PCR method can be used as an important technique in the diagnosis of virulence genes (invA and stn) of Salmonella serotypes. In addition to the importance of invA gene that could be used as a marker for rapid and accurate detection of Salmonella species (Fekry et al., 2018)

The standard conventional cultural techniques to identify Salmonella spp. are time-consuming and can require up to 5 days for confirmation. Polymerase chain reaction (PCR) based methods combine simplicity with a potential for high specificity and sensitivity in detection of Salmonella. Amplification of invA gene of Salmonella has been reported as a suitable target for PCR amplification, with potential diagnostic applications (Malorny et al., 2003).

Pathogenic processes in salmonellosis are dictated by an array of factors that act in tandem and ultimately manifest in the typical symptoms of salmonellosis. Virulence genes encode products that assist the organisms in expressing its virulence in the host cells. Nucleic acid based techniques are being employed for the detection of various gene-encoded virulence factors invA and avrA genes that associated with Salmonella pathogenicity islands (SPIs), and stn involved in enterotoxin production (Muthu et al., 2014). Studies indicated that Salmonella species, which putatively possess virulence genes such as hilA and inv A, are consistently associated with severe illness compared with those, which lack such genes (Castagna et al., 2005).

Because of the continuous consumer demands worldwide for eggs, periodical assessment is required to offer safe and good quality eggs for consumption, Therefore, this study was designed to determine the incidence of Salmonella species in egg content of both farm and balady eggs, In addition, investigation the presence of virulence genes (avrA, invA and stn) in the isolated Salmonella species.

\section{MATERIALS AND METHODS}

\section{Collection of samples:}

Four hundred samples of edible eggs (200 farm eggs and 200 balady eggs) were collected randomly from different supermarkets and farms in El-Behera Governorate. Eggs were collected in sterile polyethylene bags and transferred in refrigerated containers to the laboratory for bacteriological investigation according to (Moosavy et al., 2015).

\section{Bacteriological examination:}

2.1. Preparation of egg content for culturing according to (Zubair et al., 2017)

The egg surface was sterilized by immersion in $70 \%$ alcohol for $2 \mathrm{~min}$, air dried for 10 minutes and then cracked with a sterile knife. Egg contents were pipetted and poured into a sterile jar and homogenized.

\subsection{Isolation and identification of Salmonella species (ISO, 2002)}

For pre-enrichment, 1:10 dilution in buffered peptone water was prepared from homogenized egg content at ambient temperature and incubated for $18 \pm 2$ hours for $37^{\circ} \mathrm{C} \pm 1^{\circ} \mathrm{C}$. Selective enrichment was applied by addition of $0.1 \mathrm{ml}$ of culture to $10 \mathrm{ml}$ of Rappaport vassiliadis (RV) broth and incubated for 24 hours at $41.5^{\circ} \mathrm{C} \pm 1^{\circ} \mathrm{C}$. Then a loopful of $\mathrm{RV}$ culture was streaked onto Xylose Lysine Deoxycholate agar (XLD) plates, plus Brilliant Green agar and incubated at $37^{\circ} \mathrm{C}$ for 24 hours. The pure red colonies with black centers suspected Salmonella were subjected to biochemical screening such as; sugar fermentation and $\mathrm{H}_{2} \mathrm{~S}$ production on triple sugar iron agar, decarboxylation of lysine, $\beta$ galactosidase reactions, indole production in tryptone broth and urea splitting ability in Christensen's urea agar according to (Cruickshank et al., 1975).

\section{Serotyping of Salmonella species}

All Salmonella isolates were subjected to serological typing by slide agglutination test in serological unit, Animal Health Research Institute, Dokki, Giza according to Grimont and Weill (2007). Only fresh bacterial cultures from 24 hours age colonies onto nutrient agar media were used.

\section{PCR techniques:}

DNA extraction DNA extraction from pure isolates (five isolates of $S$. enteritidis and one isolate of $S$. typhimurium) and direct egg content was done using the QIAamp DNA mini kit (Qiagen S.A., Courtaboeuf Cedex, France) with modifications from the manufacturer's recommendations. Briefly, $200 \mu 1$ of the sample suspension was incubated with 
$200 \mu \mathrm{l}$ of $\mathrm{AL}$ Buffer for $10 \mathrm{~min}$ at $56^{\circ} \mathrm{C}$. After incubation, $200 \mu 1$ of $100 \%$ ethanol was added to the lysate. The sample was then washed and centrifuged following the manufacturer's recommendations. Nucleic acid was eluted with $100 \mu$ l of elution buffer provided in the kit.

Oligonucleotide Primer: Primers used were supplied from Metabion, Germany are listed in a Table 1. Primers were utilized in a $25-\mu 1$ reaction containing $12.5 \mu \mathrm{l}$ of EmeraldAmp Max PCR Master Mix (Takara, Japan), $1 \mu$ l of each primer of $20 \mathrm{pmol}$ concentration, $4.5 \mu \mathrm{l}$ of water, and $6 \mu \mathrm{l}$ of
DNA template. The reaction was performed in a T3 Biometra thermal cycler. The products of PCR were separated by electrophoresis on $1.5 \%$ agarose gel (Applichem, Germany, GmbH) in 1x TBE buffer at room temperature using gradients of $5 \mathrm{~V} / \mathrm{cm}$. For gel analysis, $20 \mu \mathrm{l}$ of the products were loaded in each gel slot. Gelpilot 100 bp ladder (Qiagen) and Gene ruler 100 bp DNA ladder (Fermentas) were used to determine the fragments sizes. The gel was photographed by a gel documentation system (Alpha Innotech, Biometra) and the data was analyzed through computer software.

Table 1: Oligonucleotide primers used in the study and their cycling conditions.

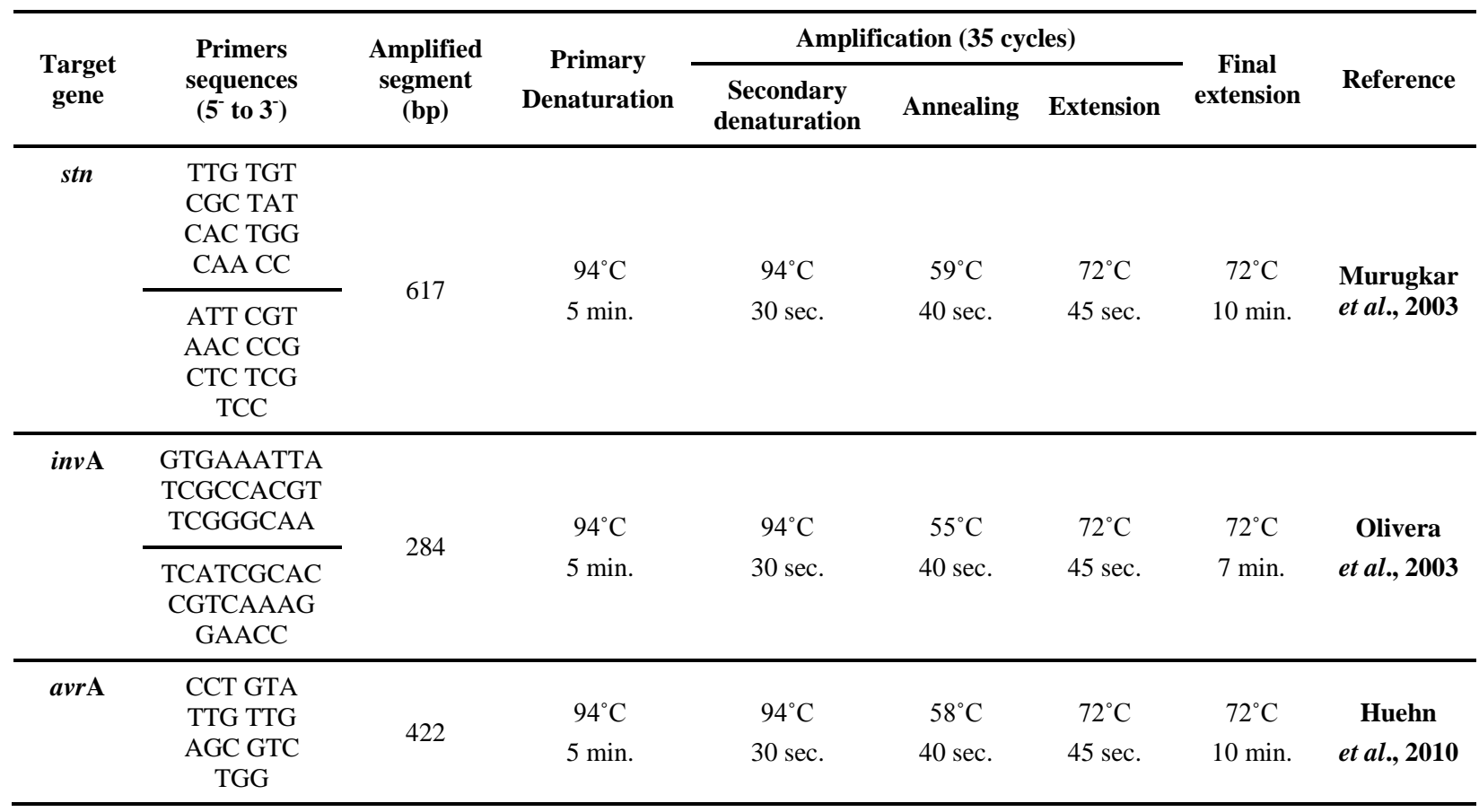

\section{RESULTS}

Table 2: Incidence of Salmonella species in examined farm and balady egg content.

\begin{tabular}{cccccc}
\hline & \multirow{2}{*}{$\begin{array}{c}\text { No. of examined } \\
\text { stems }\end{array}$} & \multicolumn{2}{c}{ Positive samples } \\
\cline { 3 - 5 } & & Organism isolation* & \multicolumn{2}{c}{ Direct gene detection** } \\
\cline { 3 - 6 } & 200 & 2 & $\%$ & No & 0 \\
\hline Farm egg & 200 & 6 & 3 & 0 & 1 \\
\hline Balady egg & 400 & 8 & 2 & 2 & 0.5 \\
\hline Total & & No & 1 & 2 \\
\hline
\end{tabular}

*Isolation of Salmonella species by conventional method then confirmed by PCR.

**Direct detection of virulent genes of Salmonella species from egg content samples by direct molecular identification. 


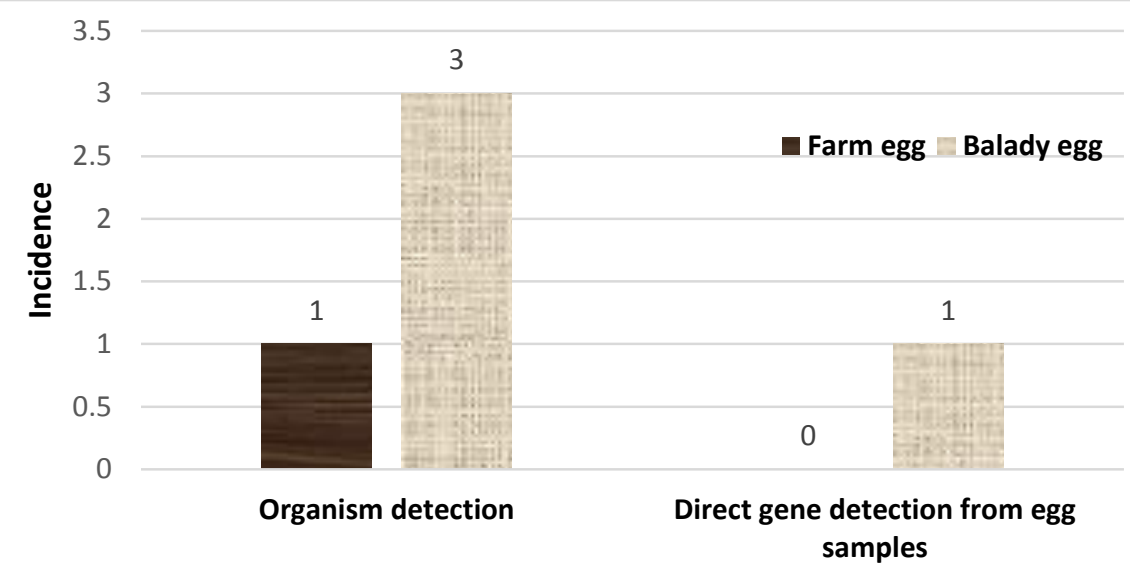

Figure 1: Detection of Salmonella species by conventional method and direct gene detection in egg content samples.

Table 3: Serotyping of Salmonella serovars isolated from examined farm and balady egg contents.

\begin{tabular}{cccccc}
\hline \multirow{2}{*}{ Serotyping } & \multicolumn{2}{c}{ Farm eggs } & \multicolumn{2}{c}{ Balady eggs } & \multirow{2}{*}{ Antigenic structure } \\
\cline { 2 - 6 } & No & $\%$ & No & $\%$ & \\
\hline Salmonella enteritidis & 1 & 0.5 & 5 & 2.5 & $1,9,12: \mathrm{g}, \mathrm{m}$ \\
\hline Salmonella typhimurium & 1 & 0.5 & 1 & 0.5 & $1,4,5,12: \mathrm{i}: 1,2$ \\
\hline
\end{tabular}

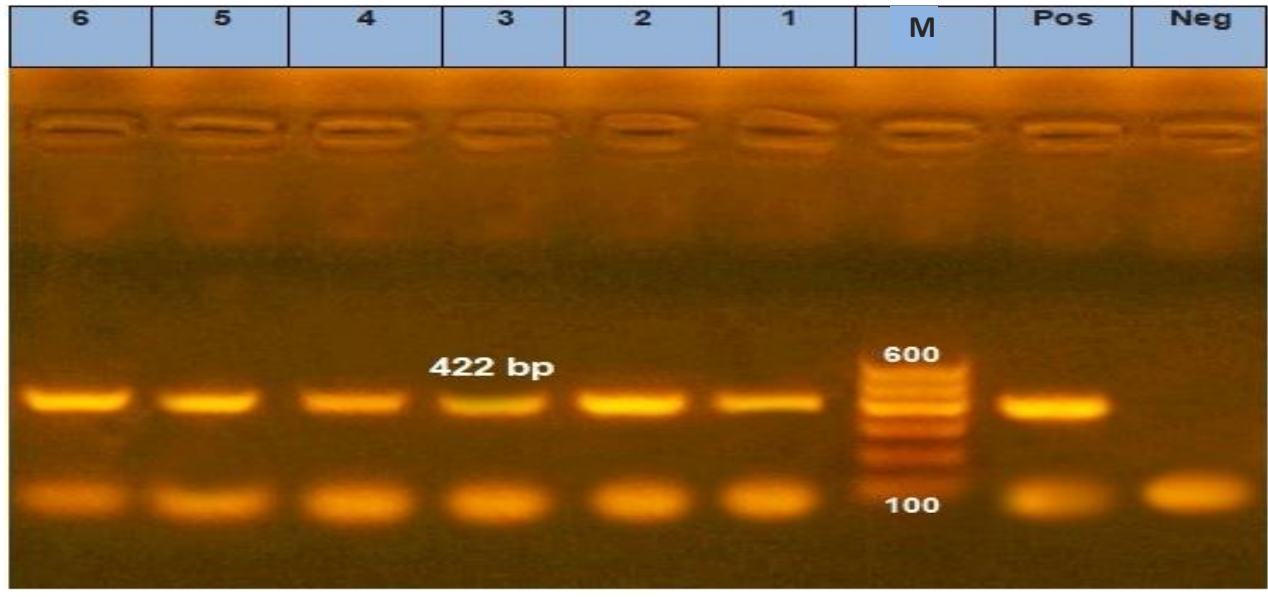

Figure 2: Agarose gel electrophoresis showing amplified PCR product of avrA gene. Lane M: 100 bp DNA Ladder, Lane 1-6: Salmonella isolates with avrA positive amplicons (422 bp)

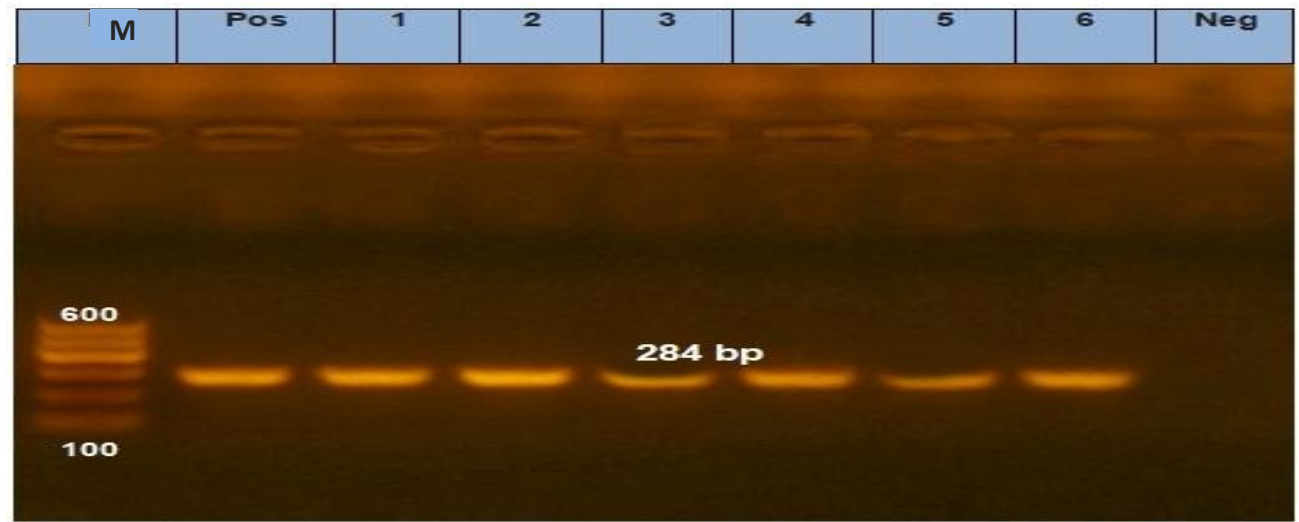

Figure 3: Agarose gel electrophoresis showing amplified PCR product of invA gene. Lane M: 100 bp DNA Ladder, Lane 1-6: Salmonella isolates with invA positive amplicons (284 bp) 


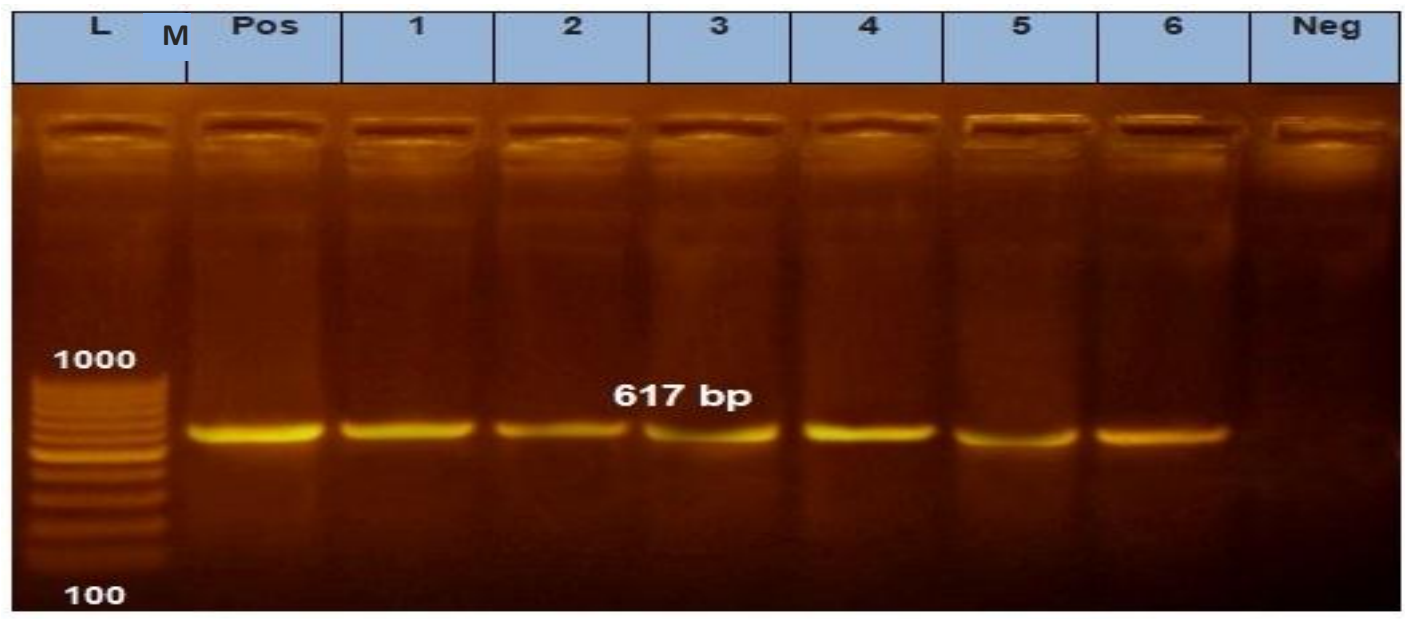

Figure 4: Agarose gel electrophoresis showing amplified PCR product of stn gene. Lane M: 100 bp DNA Ladder, Lane 1-6: Salmonella isolates with stn positive amplicons (617 bp)

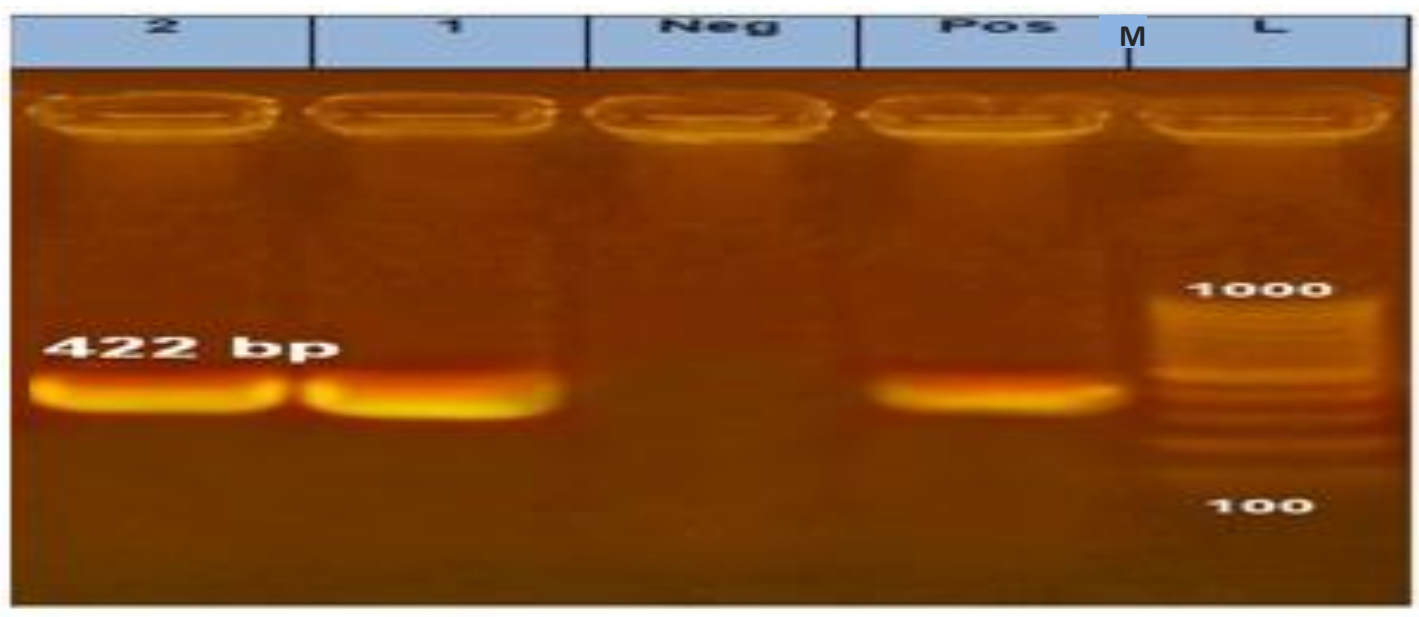

Figure 5: Agarose gel electrophoresis showing amplified PCR product of avrA gene from ten direct egg content samples. Lane M: 100 bp DNA Ladder, Lane 1-2: Salmonella isolates with avrA positive amplicons (422 bp)

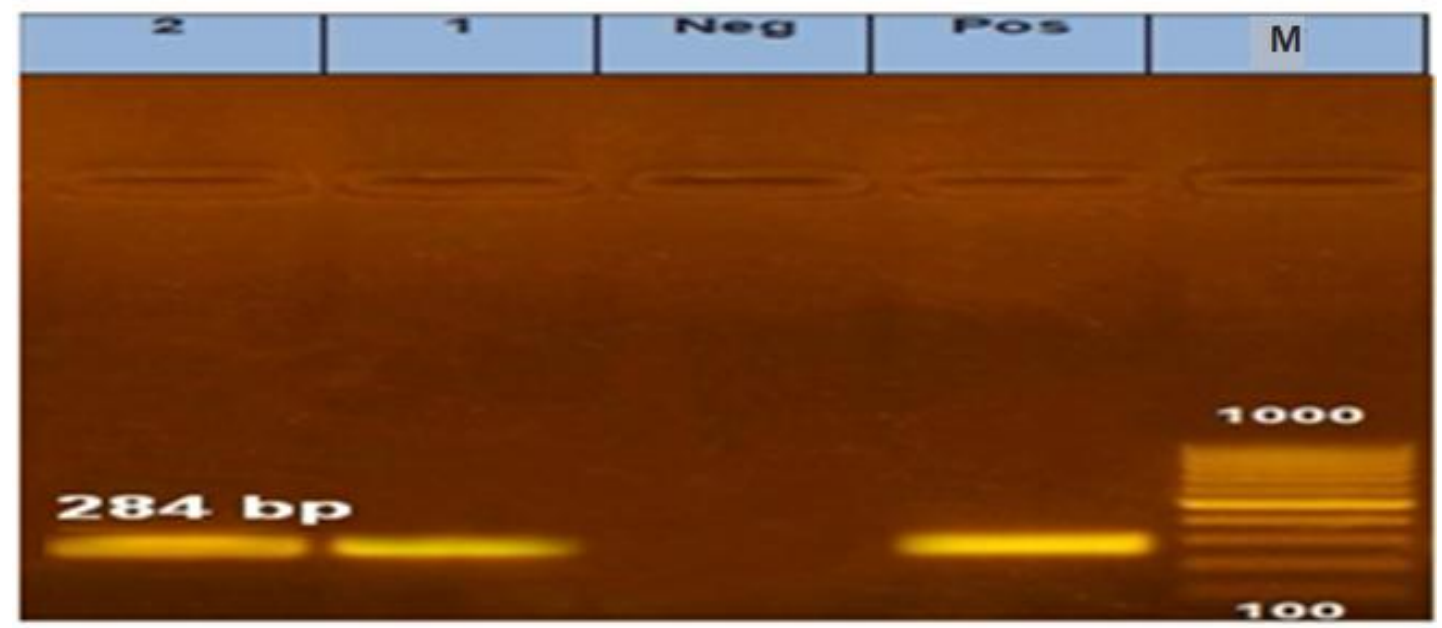

Figure 6: Agarose gel electrophoresis showing amplified PCR product of invA gene from ten direct egg content samples. Lane M: 100 bp DNA Ladder, Lane 1-2: Salmonella isolates with invA positive amplicons (284 bp) 


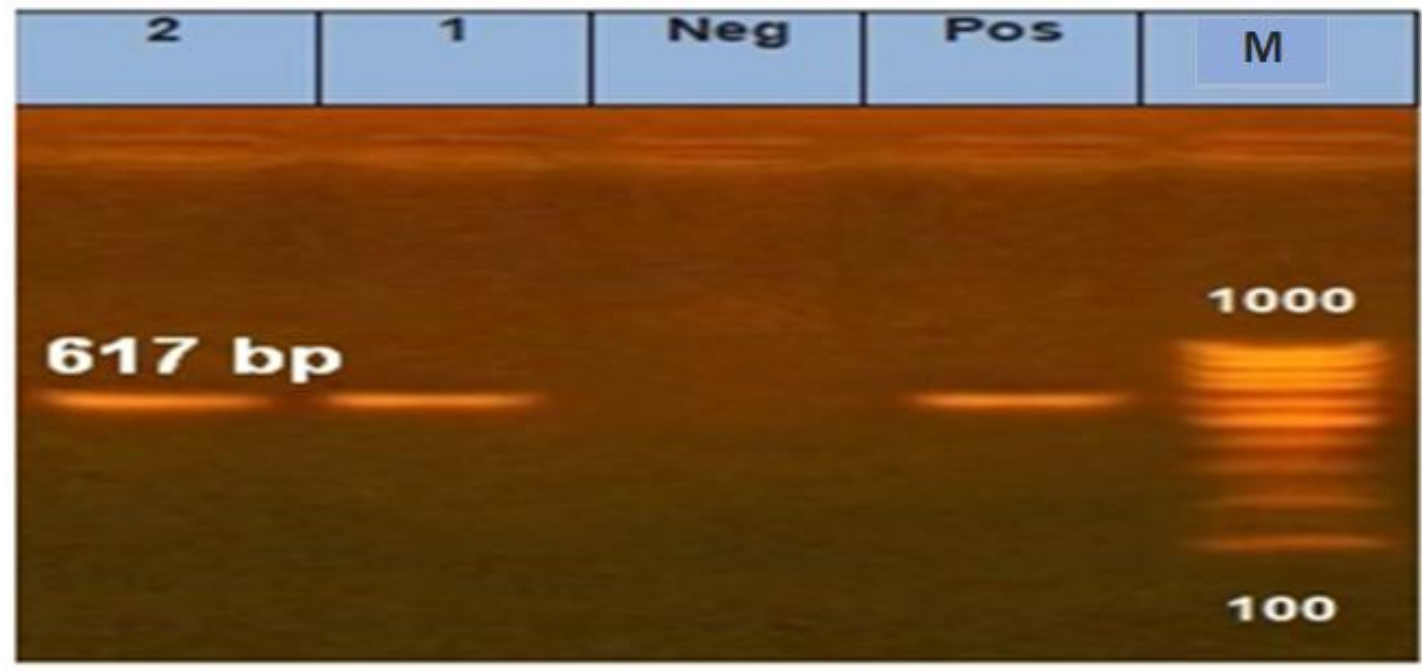

Figure 7: Agarose gel electrophoresis showing amplified PCR product of stn gene from ten direct egg content samples. Lane M: 100 bp DNA Ladder, Lane 1-2: Salmonella isolates with sth positive amplicons (617 bp)

\section{DISCUSSION}

Salmonella has the ability to persist on the surface of the egg shell and contaminate the content of egg when eggs are broken for preparation of food, which could pose a potential health risk to the society. Therefore, removal of the wastes and disinfection can greatly reduce Salmonella contamination on the shell and the content (Omwandho and Kubota, 2010).

The obtained results in Table 2 and figure 1 declared that the incidence of Salmonella in egg content of totally examined eggs was $2 \%(8 / 400)$ distributed as $2 / 200(1 \%)$ in farm eggs, while incidence in balady eggs was $3 \%(6 / 200)$, this may be due to that balady eggs were more contaminated with faecal matter than farm eggs which have high level of hygienic measures during production. The aforementioned results revealed that incidence of Salmonella by direct gene detection using molecular identification was two (1\%) from balady eggs while failed to be detected in farm eggs.

Nearly similar incidence of Salmonella in egg content was reported by Awny et al. (2018) who reported that incidence of Salmonella in egg contents of examined farm eggs was $4 \%$. On the contrary, the same authors failed to detect Salmonella in egg contents of examined balady eggs. In addition, Zubair et al. (2017) failed to detect Salmonella in egg content of 350 examined eggs in Iraq. Also, Moosavy et al. (2015) could not isolate Salmonella from egg content of 150 examined commercial eggs collected from local stores in Iran.

EOSQC (2007) stated that the fresh table eggs should be free from Salmonellae species in their contents. According to these standards, the percentages of samples that failed to comply with the standards were 1 and $3 \%$ in farm and balady egg contents, respectively.

Contamination of egg shells represents a serious risk for the consumers, as they can directly infect and cross-contaminate the egg contents or other foodstuffs (Martelli and Davies, 2012). Salmonella may be able to contaminate egg contents by migration through the egg shell and membranes; such route, facilitated by moist egg shells, storage at ambient temperature and shell damage (Zeidler, 2002). The motility of Salmonella on egg shells may easily penetrate the shells to interior; the rate of penetration is influenced by humidity and storage temperature at which the eggs were produced and stored (Cox et al., 2000).

The obtained results in Table 3 revealed that serotyping of Salmonella species in examined farm eggs was one strain Salmonella enteritidis serotyped $(1,9,12: \mathrm{g}, \mathrm{m})$ and one strain Salmonella typhimurium serotyped $(1,4,5,12: \mathrm{i}: 1,2)$. Meanwhile, in examined balady eggs were five strains $(2.5 \%)$ Salmonella enteritidis serotyped as $(1,9,12: \mathrm{g}, \mathrm{m})$ and one strain $(0.5 \%)$ Salmonella typhimurium serotyped as $(1,4$, 5, 12:i:1, 2).

Historically, $S$. typhimurium is the most frequently serovars and $\mathrm{S}$. enteritidis is the second as causative agents of human gastroenteritis throughout the world and were isolated from cases of food poisoning and represents about 50-60 of the cases (Sharma et al. 1996).

In the present study, both serovars of $S$. enteritidis and typhimurium were identified. Jamshidi et al. 
(2010) could isolate $S$. enteritidis and Miranzadeh et al. (2012) could isolate $S$. typhimurium from eggs.

Salmonella enteritidis is the most prevalent serovar in the world (Betancor et al., 2010; Sasaki et al., 2011). Few eggs related outbreaks of salmonellosis caused by $S$. typhimurium were reported in humans in the European Union (3.5\% against $77.2 \%$ caused by $S$. enteritidis (EFSA, 2010).

Figure 2 showed that, all 6 (100\%) Salmonella isolates were found to carry $a v r \mathrm{~A}$ gene. The amplified PCR products of all Salmonella isolates on agarose gel electrophoresis yielded a $422 \mathrm{bp}$ product in the avrA gene segment.

The virulence-associated effector protein avrA of $S$. enterica, which interferes with the first line of immune response of the target organism (CollierHyams et al., 2002), is an important partner in the virulence phenotype of this pathogen (BenBarak et al., 2006)

Presence of invA gene confirms the invasive strains of Salmonella at the genus level. In the present study, all 6 (100\%) Salmonella isolates were found to carry invA gene. The amplified PCR products of all salmonella isolates on agarose gel electrophoresis yielded a $284 \mathrm{bp}$ product in the invA gene segment (Figure 3). It is speculated that strains without invA gene are not invasive, or that they might be using other invasive mechanisms. However, their absence in Salmonella seems to be rare (Malorny et al., 2003).

The obtained data nearly agree with results obtained by Nagappa et al. (2007) who could isolated Salmonella typhimurium from eggs at incidence of $3 \%(3 / 100)$ in India, molecular identification using PCR revealed 3 isolates have invA gene amplified at $284 \mathrm{bp}$

Figure 4 revealed that, all $6(100 \%)$ Salmonella isolates were found to carry stn gene. The amplified PCR products of all Salmonella isolates on agarose gel electrophoresis yielded a 617 bp product in the stn gene segment.

Recorded results were similar to that obtained by Naik et al. (2015) who revealed that stn gene was present in all the isolates $(100 \%)$ irrespective of source of samples and region of sampling, Stn gene in Salmonella is highly conserved and it is expected to be a new target gene for detection of Salmonellae in field samples. Salmonella induced diarrhea is a complex phenomenon involving several pathogenic mechanisms including production of enterotoxin (Baloda et al., 1983) which is mediated by the $s t n$ gene (Chopra et al., 1987).
Most $S$. enterica strains (approximately $\quad 80 \%$ ) contain the avrA gene as mentioned by Streckel et al. (2004). In addition, Diarra et al. (2014) found that the invasion gene (invA) present in $97.9 \%$ of Salmonella enterica serovars and the heat-labile Salmonella enterotoxin (stn) serve as effector proteins, which are involved in the pathogenesis of salmonellosis, so the primer sets designed in the present study for invA, avrA and stn genes allow simultaneous identification of all pathogenic Salmonella within the genus level.

Figures 5, 6 and 7 showing that two samples of five egg content samples from balady eggs were positive for target virulence gene including $a v r \mathrm{~A}$, inv A and stn genes at molecular weight 422, 284 and $617 \mathrm{bp}$, respectively while failed to be detected from five farm egg content samples.

The use of Salmonella specific PCR with primers inv $\mathrm{A}$ is rapid, sensitive and more specific for detection of Salmonella in many food samples. The amplification of invA gene has been validated as a standard for detection of invasion gene from Salmonella species (Ferretti et al., 2001).

The PCR method using target gene remains a suitable molecular tool to diagnose Salmonella in animals. These findings have important health implications to the entire populace considering the high prevalence of virulence genes in food samples studied and it also underscores the need for rapid identification of Salmonella virulence genes using the PCR method (Stella et al., 2015)

In general, egg-related outbreaks resulted from breakdowns in controlling measurements along the farm to fork continuum. International poultry control programs in developed countries have resulted in significant decreases in egg-related salmonellosis. These programs included; on-farm monitoring, diverting contaminated eggs for processing, culling infected flocks, cleaning and disinfection of sheds, maintaining cold chain of eggs, and vaccination of flocks (Moffatt and Musto, 2013). It is recommended that these controlling measurements should be done carefully in all countries including Egypt.

\section{CONCLUSION AND RECOMMENDATION}

From this study, Salmonella is an important causative agent for food poisoning outbreaks worldwide. The most common implicated food is egg or egg containing dishes. Eggs may be a source of transmission of Salmonellosis. Salmonella pathogenicity islands (SPIs) along with the virulence plasmids play an important role in survival and proliferation of bacteria in host system. PCR can be used as an alternative tool to the conventional 
isolation and identification methods for the rapid detection of Salmonellae. Therefore, food handlers and the public should be encouraged to ensure good personal hygiene practices and proper cooking/food handling procedures through various trainings and education.

\section{REFERENCES}

Ahmed, A.; Hajime, F.; Takuya, M. and Takayuki, E. (2014): Isolation of Salmonella from Liquid Whole Eggs Sold in Retail Outlets in Egypt, Bangladesh and not in Japan. Advances in Animal and Veterinary Sciences 2 (7): 390 392.

Awny, C.; Amr A. Amer and Hussein S. Abo ElMakarem (2018): Microbial Hazards Associated with Consumption of Table Eggs. Alexandria Journal of Veterinary Sciences, 58 (1): 139-146.

Baloda, S.B.; Faris, A.; Krovacek, K. and Wadstrom, T. (1983): Cytotonic enterotoxins and cytotoxic factors produced by Salmonella Enteritidis and Salmonella Typhimurium. Toxicon, 21(6): 785-796.

Ben-Barak, Z.; Streckel, W.; Yaron, S.; Cohen, S.; Prager, R. and Tschäpe, H. (2006): The expression of the virulence-associated effector protein gene $a v r \mathrm{~A}$ is dependent on a Salmonella Enterica-specific regulatory function. Int. J. Med. Microbiol., 296: 25-38.

Betancor, L.; Pereira, M.; Martinez, A.; Giossa, G.; Fookes, M. and Flores, K. (2010): Prevalence of Salmonella Enterica in poultry and eggs in Uruguay during an epidemic due to Salmonella Enterica serovar Enteritidis. J Clinical Microbiol., 48:2413-2423.

Castagna, S.M.F.; Muller, M.; Macagnan, M.; Rodenbusch, C.R.; Canal, C.W. and Cardoso, M. (2005): Detection of Salmonella sp. from porcine origin: a comparison between a PCR method and standard microbiological techniques. Brazilian Journal of Microbiology, vol. 36(4): 373-377.

Chopra, A.K.; Houston, C.W.; Peterson, J.W.; Prasad, R. and Mekalanos, J.J. (1987): Cloning and expression of the Salmonella enterotoxin gene. J. Bacteriol., 169(11): 5095-5100.

Collier-Hyams, L.S.; Zeng, H.; Sun, J.; Tomlinson, A.D.; Bao, Z.Q.; Chen, H.; Madara, J.L.; Orth, K. and Neish, A.S. (2002): Cutting edge: Salmonella avrA effector inhibits the key proinflammatory, anti-apoptotic NF- $\mathrm{B}$ pathway. J Immunol 169, 2846-2850.

Cox, N.A.; Berrang, M.E. and Cason, J.A. (2000): Salmonella penetration of eggshells and proliferation in broiler hatching eggs--a review. Poult. Sci., 79(11):1571-4.

Cruickshank, R.; Duguid, J.P.; Marmion, B.P. and Swain, R.H.A. (1975): Medical microbiology.
The practice of Medical Microbiology. $12^{\text {th }}$ Ed. Vol. II Churchill Living stone, Edinburgh, London and New York. 1975. 2: 170-188

Diarra, M.S.; Delaquis, P. and Rempel, H. (2014): Antibiotic resistance and diversity of Salmonella Enterica serovars associated with broiler chickens. J. Food Protection, 77 (1): 40-49.

EFSA (European Food Safety Authority) (2010): Scientific opinion on a quantitative estimate of the public health impact of setting a new target for the reduction of Salmonella in laying hens. EFSA J., 8:1546.

EOSQC, Egyptian Organization for Standardization and Quality Control (2007): Fresh table eggs. Egyptian Standards, Ministry of Industry. Cairo. Egypt.

Fekry, E.; Eman-Abdeen, E.; Ahmed, M.A. and Alaa-Edin, H. (2018): Molecular Detection of InvA, OmpA and Stn Genes in Salmonella Serovars from Broilers in Egypt. Alexandria Journal of Veterinary Sciences, 56 (1):69-74.

Ferretti, R.; Mannazzu, L.; Cocolin, L.; Comi, G. and Clementi, F. (2001): Twelve-hour PCRbased method for detection of Salmonella spp in food. Appl. Environ. Microbiol. 74: 977978. 2001

Gal-Mor, O.; Boyle, EC. and Grassl, GA. (2014): "Same species, different diseases : how and why typhoidal and non-typhoidal Salmonella Enterica serovars differ"Frontiers in microbiology.5:391.

Doi:10.3389/fmicb.2014.00391.PMC 4120697.PMID 25136336.

Gast, R.K.; Guraya, R.; Guard, J. and Holt, PS. (2011): The relationship between the numbers of Salmonella Enteritidis, Salmonella Heidelberg, or Salmonella Hadar colonizing reproductive tissues of experimentally infected laying hens and deposition inside eggs. Avian Dis 55: 243-247.

Grimont, P.A. and Weill, F.X. (2007): Antigenic formulae of the salmonella serovars. WHO Collaborating Centre for Reference and Research on salmonella, Institute Pasteur, Paris, France.

Hensel, M. (2004): Evolution of pathogenicity islands of Salmonella Enterica. Int. J. Med. Microbiol., 294: 95-102.

Huehn, S.; La Ragione, R.M.; Anjum, M.; Saunders, M.; Woodward, M.J.; Bunge, C.; Helmuth, R.; Hauser, E.; Guerra, B.; Beutlich, J.; Brisabois, A.; Peters, T.; Svensson, L.; Madajczak, G.; Litrup, E.; Imre, A.; HerreraLeon, S.; Mevius, D.; Newell, D.G. and Malorny, B. (2010): Virulotyping and antimicrobial resistance typing of Salmonella Enterica serovars relevant to human health in Europe, Foodborne Pathog. Dis., 7: 523-535. 
International Standard, (ISO, 6579/2002): Microbiology of food and animal feeding stuffs-Horizontal method for detection of Salmonella spp. $4^{\text {th }}$ ed. Genev: International Organization for Standardization, 27str.

Jamshidi, A.; Kalidari, G. and Hedayati, M. (2010): Isolation and identification of Salmonella Enteritidis and Salmonella Typhimurium from the eggs of retail stores in Mashhad, Iran using conventional culture method and multiplex PCR assay. J Food Safety; 30: 558568.

Jay, J.M.; Golden, D.A. and Loessner, M.J. (2005): Modern Food Microbiology. $7^{\text {th }}$ Edition. ISBN: 978-0-387-23180-8, Publisher. Springer Verlag.

Jones, D.R. (2006): Conserving and monitoring shell egg quality. Proceedings of the 18th Annual Australian Poultry Science Symposium, February 20-22, 2006, Australia, 157-165.

Malorny, B.; Bunge, C. and Helmuth, R. (2003): Discrimination of d-tartrate-fermenting and non-fermenting Salmonella Enterica subsp. enterica isolates by genotypic and phenotypic methods. J. Clin. Microbiol., 41(9):42924297.

Martelli, F. and Davies, R.H. (2012): Salmonella serovars isolated from table eggs: An overview. Food Res Int., 45(2):745-54.

Miranzadeh, H.; Zahraei, S.T. and Karimi, V. (2012): The count of aerobic mesophill bacteria and isolate Salmonella species on egg in Isfahan. J Veterinary Journal (Pajouhesh-vaSazandegi), 25:31-36.

Moffatt, C. and Musto, J. (2013): Salmonella and egg-related outbreaks. Microbiol. Aust., 34:94-98.

Moosavy, M.H.; Saber, E.; Fahimeh, B.A.; Ehsan, M. and Taghi, Z.S. (2015): Detection of Salmonella spices in commercial eggs in Iran. Iran. J. Microbiol., 7(1): 50-54

Murugkar, H.V.; Rahman, H. and Dutta, P.K. (2003): Distribution of virulence genes in Salmonella serovars isolated from man \& animals. Indian J Med Res., 117: 66-70.

Muthu, G.; Suresh, A.; Vishnuprabu, D.; Munirajan, A.K.; Esther Mary, S.; Sathishkumar, E.; Gopinath, P. and Srivani, S. (2014): Detection of virulence genes from Salmonella species in Chennai, India. CIB Tech J. Microbiol., 3:11-14.

Nagappa, K.; Shantanu, T.; Brajmadhuri, Saxena M.K. and Singh, S.P. (2007): Isolation of Salmonella Typhimurium from poultry eggs and meat of Tarai region of Uttaranchal. Indian Journal of Biotechnology, 6: 407-409

Naik, V.K.; Sanjay, S.; Anil, P. and Nitin, E.G. (2015): Detection of Virulence Genes in Salmonella Species Isolated from Chevon and Chicken Meat. Journal of Animal Research, 5 (1): 115-118.
Olivera, S.D.; Rodenbusch, C.R.; Ce, M.C.; Rocha, S.L.S. and Canal, C.W. (2003): Evaluation of selective and non-selective enrichment PCR procedures for Salmonella detection. Lett. Appl. Microbiol., 36: 217-221.

Omwandho, C.O.A. and Kubota, T. (2010): Salmonella Enterica serovar Enteritidis: A mini-review of contamination routes and limitations to effective control. Japan Agric. Res. Q., 44(1):7-16.

Poppe, C.; Duncan, C.L and Mazzocco, A. (1998): Salmonella Contamination of Hatching and Table Eggs: A Comparison. Can J Vet Res., 62(3): 191-8.

Ricke, S.C.; Birkhold, S.G. and Gast, R.K. (2001): Eggs and egg products. In compendium of methods for the microbiological examination of foods. Fourth edition. American Public Health Association. Washington. Downes F. P. and Ito K. eds. P.473-479.

Samiullah, J.R.R. and Chousalkar, K.K. (2014): Effect of production system and flock age on egg quality and total bacterial load in commercial laying hens. J. Appl. Poult. Res. 23: 59-70.

Sasaki, Y.; Tsujiyama, Y.; Asai T.; Noda, Y.; Katayama, S. and Yamada, Y. (2011): Salmonella prevalence in commercial raw shell eggs in Japan: a survey. Epidemiol Infect., 139:1060-1064.

Shah, D.H.; Zhou, X.; Addwebi, T.; Davis, M.A.; Orfe, L.; Call, D.R.; Guard, J. and Besser, T.E. (2011): Cell invasion of poultryassociated Salmonella enterica serovar Enteritidis isolates is associated with pathogenicity, motility and proteins secreted by the type III secretion system. Microbiology 157:1428-1445.

Sharma, D.; Sharma, V. and Kumar, A. (1996): Microbial of commercial meat products. Ind. J. Animals Sci., 66(2):211-213.

Stella, I.S.; Muinah, A.F.; Adedamilola, T.; Joseph, A.; Tina, F.; Mary, E.A.; Emmanuel, A. O.; Margaret, I.U.; Moses, B. and Peter, O. (2015): Molecular Detection of Some Virulence Genes in Salmonella Spp Isolated from Food Samples in Lagos, Nigeria. Animal and Veterinary Sciences. Vol. 3, No. 1: pp. 22-27

Streckel, W.; Wolff, A. C.; Prager, R.; Tietze, E. and Tschape, H. (2004): Expression profiles of effector proteins SopB, SopD1, SopE1, and AvrA differ with systemic, enteric, and epidemic strains of Salmonella Enterica. Mol. Nutr. food Res., 48 (7): 496-503.

Suez, J.; Porwollik, S.; Dagan, A.; Marzel, A.; Schorr, Y.I.; Desai, P.T.; Agmon, V.; McClelland, M.; Rahav, G. and Gal-Mor, O. (2013): Virulence gene profiling and pathogenicity characterization of non- 
typhoidal Salmonella accounted for invasive disease in humans. PLoS One8 (3): e58449.

Tan, T.C.; Kanyarat, K. and Azhar, M.E. (2012). Evaluation of Functional Properties of Egg White Obtained from Pasteurized Shell Egg as Ingredient in Angel Food Cake. International Food Research Journal, 19(1): 303-308.
Zeidler, G. (2002): Microbiology of Poultry Meat Products. Commercial Chicken Meat and Egg Production (Bell DD and Weaver WD eds). Springer Science and Business Media Inc. pp. 889-898.

Zubair, A.I.; Al-Berfkani, M.I. and Issa, A.R. (2017): Prevalence of Salmonella species from poultry eggs of local stores in Duhok. Int. J. Res. Med. Sci., 5: 2468-71.

\section{التوصيف الجزيئي لأنواع السالمونيلا المعزولة من محتوي بيض دجاج المائدة}

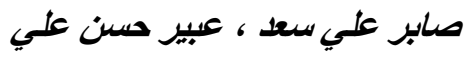

E-mail: sabersaad284@yahoo.com Assiut University web-site: www.aun.edu.eg

السالمونيلا هي أحد أهم الميكروبات التي تنتقل عن طريق الأغذية التي يحصل عليها الإنسان وخصوصا البيض الخام أو الغير مطبوخ

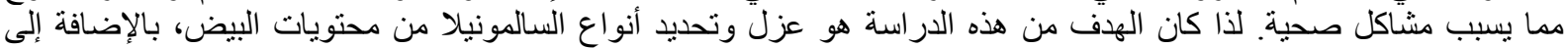

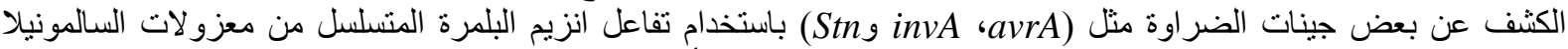

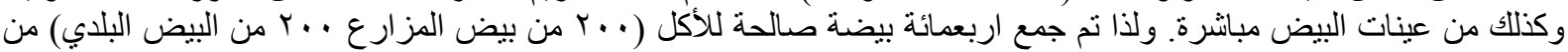

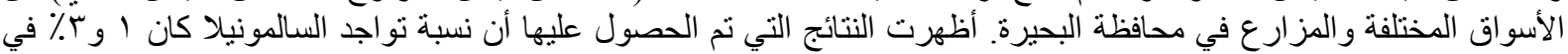

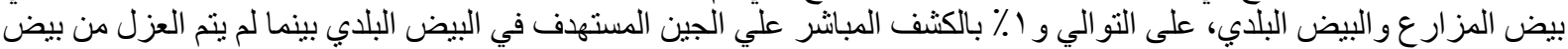

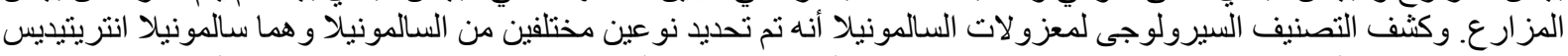

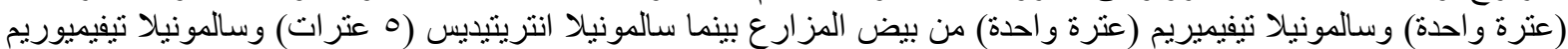

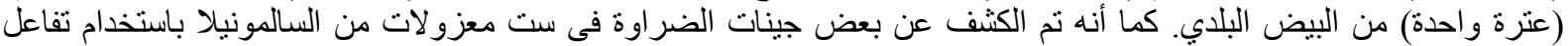

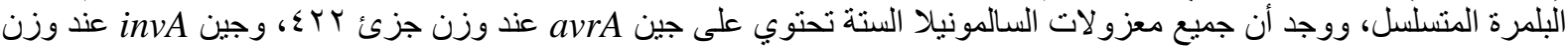

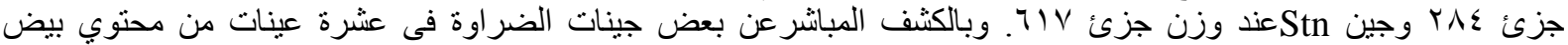

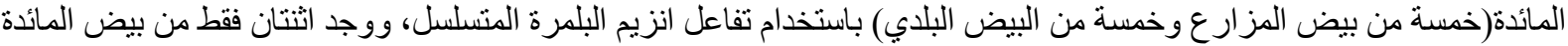

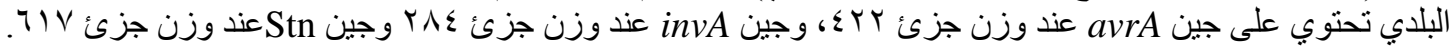

